\title{
初期変化を $\mathrm{X}$ 線的に観察し得た上顎歯槽部骨肉腫の 1 例
}

\author{
山崎慎司·佐藤敦・山口泰 \\ 松田耕策*
}

\section{Osteosarcoma of upper alveolar bone: retrospective study of early radiographic changes}

\author{
Shinji Yamazaki A Atsushi Sato Tai Yamaguchi \\ Kosaku Matsuda*
}

\begin{abstract}
We report a rare case of osteosarcoma of upper alveolar bone in which early radiographic changes from could be retrospectively examined.

A 37-year-old woman presented with an 18-month history of a persistant unusual sensation in the left upper central incisor despite endodontic treatment. The patient showed extrusion of the left upper central incisor with enlargement of the alveolar bone. Radiologic examination revealed irregular bone formation with bone and root resorption. Since histopathological diagnosis of a biopsy specimen revealed low-grade malignant osteosarcoma, surgical excision was performed. Three years after excision, no evidence of recurrence or metastasis was detected. In our patient, we could examine radiographic changes of the lesion from the early stage of tumor development.
\end{abstract}

Key words：osteosarcoma (骨肉腫), jaw (顎骨), maxilla (上顎骨)，upper alveolar bone (上顎歯槽部)

緒言

顎骨骨肉腫は部位によりその組織像がさまざまなため， 確定診断に苦慮することも少なくない。われわれは，上顎 正中部に生じた低悪性度骨肉腫の 1 例を経験し, その進展過 程をデンタル X 線写真で経時的に観察し得たので報告する.

症例
患 者: 37歳女性.
初 診: 1997年 1 月
主 訴: 左側上顎中切㐘の挺出.

家族歴・既往歴：特記事項なし。

現病歴：1995年 5 月頃より $\lfloor 1$ の違和感を自覚し, 紹 介医受診. 同歯科初診時, $\lfloor 1$ にう蝕は認められず, 電気 芷髄颜にて生活菌であった. 同年 7 月，抜髄処置を受ける

国立仙台病院歯科口腔外科

(主任：山口 泰)

*NTT 東日本東北病院蔽科口腔外科

(主任：今野俊彦)

Department of Dentistry and Oral Surgery, Sendai

National Hospital (Chief: Tai Yamaguchi)

*Department of Dentistry and Oral Surgery, NTT

East Tohoku Hospital (Chief: Toshihiko Konno)

受付日: 平成 12 年 5 月 22 日
も，違和感が消失しないため，経過観察していたところ， 1996年 2 月頃より患歯の挺出と唇側蒾肉の膨隆が発現し, 次第に増大してきたため, 同年 12 月紹介にて当科初診。な お, $\lfloor 1$ 部に打撲などの外傷の既往はなかった。

現 症:

全身所見；体格中等度，栄養状態良好。

口腔内所見; $\lfloor 1$ 唇側料肉部に無痛性, 骨様硬の膨隆を 認めた。し1は挺出していたが, 打診痛はなく, 動摇も軽 度であった (写真 $1-\mathrm{A})$.

$\mathrm{X}$ 線写真所見： $L 1 \quad 2$ 歯根間に, 境界不明瞭な骨破壊 像を認め, 内部には不均一な辺縁不整の不透過像が散在し ていた。また 1 は近心傾斜拈よび挺出しており, 歯根の 一部に吸収像が認められた（写真 1 -B). sun-ray appearanceの所見は認められない.

X 線 CT 所見： L1 㐘根周囲に境界不明瞭な骨破壊像を 劷めたが, 鼻腔底の吸収は認めなかった（写真 $2-A)$.

${ }^{99 \mathrm{~m} T c}$ 骨シンチグラム所見：骨病変に一致した部位に高 度な集積（写真 $2-B$ ) 以外に, 全身的に異常集積は認めら れなかった。なお，触診拉よびX 線 CT 所見にて, 転移を疑 わせる頸部リンパ節腫大は認められなかった。

臨床診断：上顎骨良性腫瘍の疑い

処置および経過：1997年1月ロ，第１回目の生検を施 


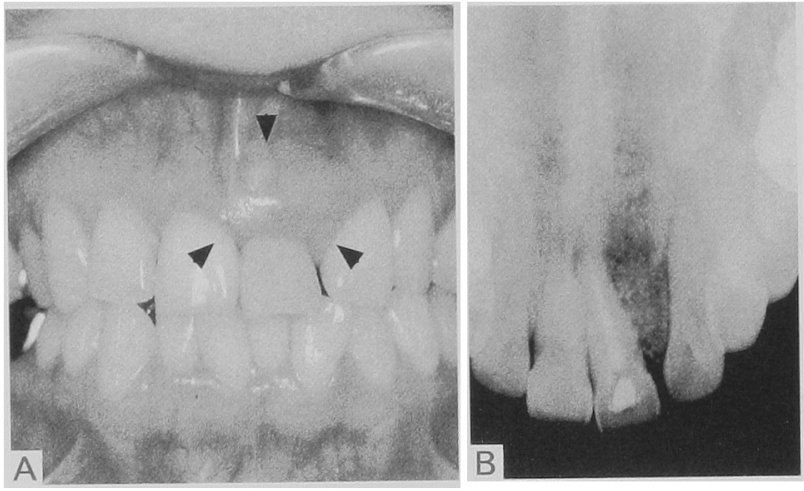

写真 1 当科初診時の口腔内およびX 線写真 (咬合法) A : 11 の挺出と唇側歯肉部の膨隆 (矢印)を認めた.

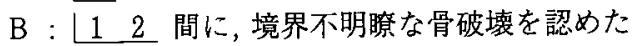
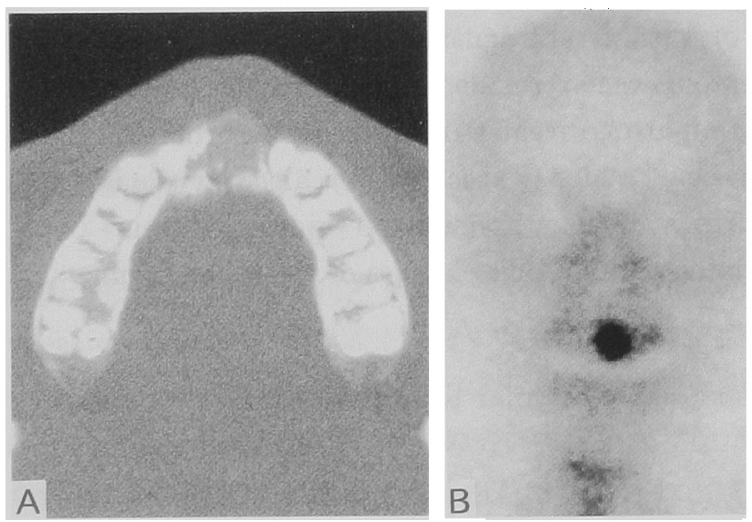

写真 2 当科初診時のCT 画像および骨シンチグラム A：【1 菊根周囲に境界不明瞭な骨破壊を認めた。 B ：骨病変に一致して高度な集積を認めた。
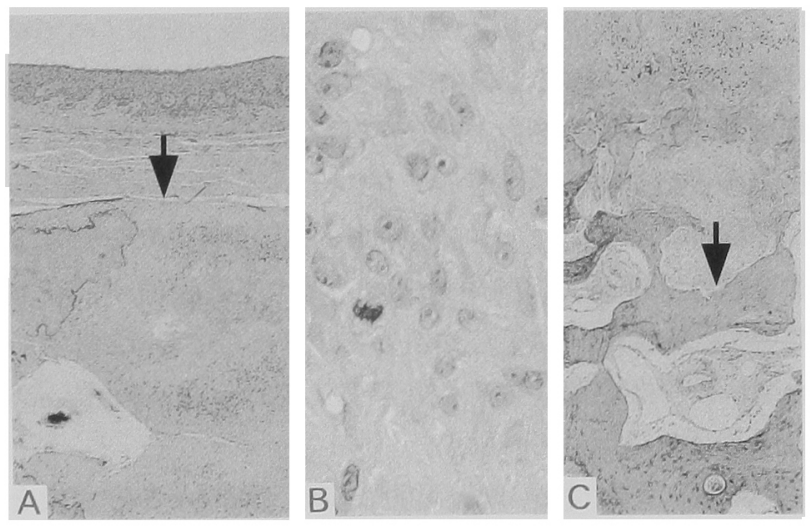

写真 3 生検時病理組織像

A：第 1 回目生検 (H-E染色, 弱拡大) 正常組織と腫演との境界は明暸であった（矢印）。

$B$ ：第 1 回目生倹 (H-E染色, 強拡大) 細胞密度は高めで, 分裂像も認められる。

C：第 2 回目生検 (H-E染色, 弱拡大) 浸潤性骨破壊像 (矢印)を認めた。
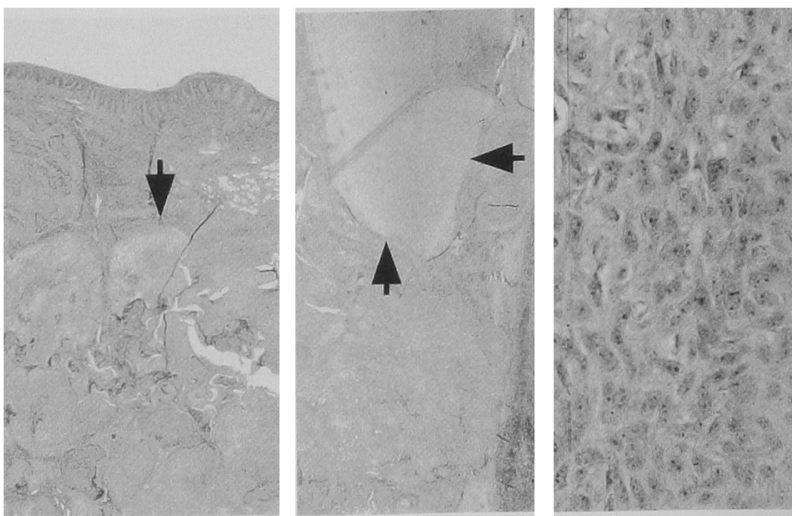

写真 4 切除物の病理組織像 (H-E 染色) 左：上皮下の骨破壊像（弱拡大）.

中: 歯根吸収像 (弱拡大).

右 : 腫緜細胞（強拡大）細胞密度は高く, 異形性も強い。

行した。病理組織学的所見では，正常粘膜下に境界明瞭な 腫湯組織を認めたが, 被膜様構造は認められなかった。腫 瘍細胞は細胞密度がやや高く，細胞分裂像も認められた (写真 3-A，B）。 また, 類骨に混じって，ごく一部に軟骨様 組織を認めた。このように，1回目の生検では明らかな悪 性所見は認められなかったが, 骨肉腫または軟骨肉腫の可 能性も完全には否定できないものと考えられたため，同年 3 月—, 2 回目の生検を施行した. 類骨はスポンジ状で, メスにて容易に切除できた. 既存の骨と腫瘍との境界部分 では, 浸潤性の骨破壊像が認められた（写真 3 -C). 以上の ように, 異型性および細胞密度があまり高度でなく，細胞 分裂像もわずかであったが，あきらかな浸潤性の骨破壊像 を認めたこと, 臨床所見では腫怚の增殖速度が緩徐であっ たものの，X線所見で歯根の吸収が認められたことから， 低恶性度の骨肉腫と診断した。

1997年 4 月—，全身麻酔下に上影部分切除術を施行 した. 10〜20mmの surgical margin を設定し， 3 |から ᄂ4 まで，上方は鼻腔底まで切除し，上唇内側には遊離植 皮を行った。術後約 3 年経過した現在, 局所再発, 頸部リン 八幯転移および遠隔転移は認められず，経過良好である。

切除物の病理組織学的所見: 上皮下まで浸潤增殖した腫 瘍が, 既存の骨を破壊している.し1 根尖部周囲は腫瘍で しめられており，歯槽骨の破壇，䇽よび歯根の吸収が認め られる.また, 生検標本に比べて細胞異型が強く，また細胞 密度が高く，核小体の著明な增加が認められた（写真 4).

病理組織学的診断：低悪性度骨肉腫.

$\mathrm{X}$ 線写真上での病変の経時的変化 (写真 $5-\mathrm{A} \sim \mathrm{E})$ ：紹 介医初診時から当科初診までの歯科用 X 線写真上におけ る,腫崵の增殖状況を観察した。

1995年 5 月（紹介医初診時）：し1 部の違和感が発現し 


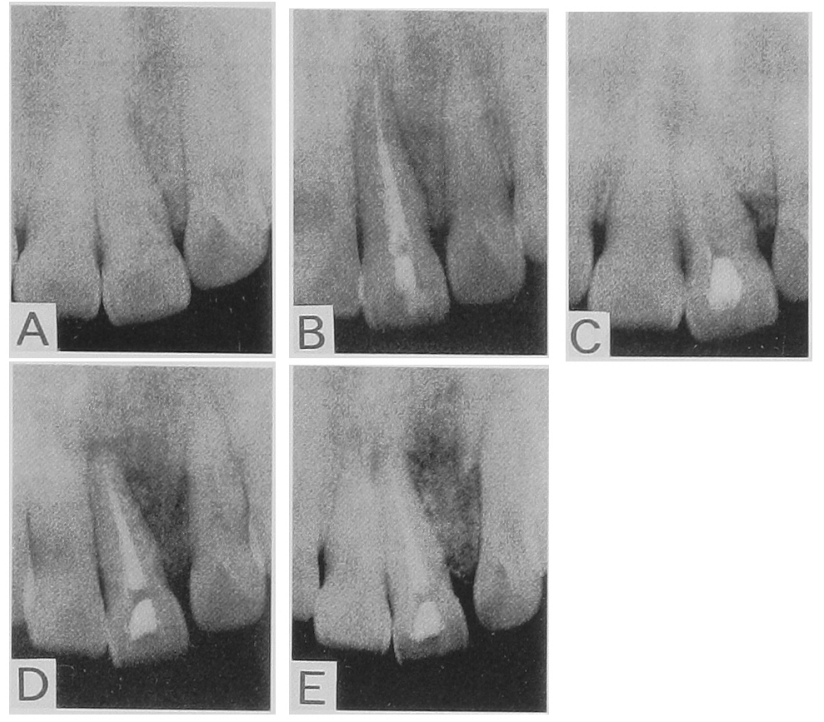

写真 5 デンタルX 線写真

$\left\lfloor\begin{array}{ll}1 & 2\end{array}\right.$ 部骨病変の経時的変化を示す

腫瘍の增大と骨破壊の様子が観察できる。
A : 1995年 5 月（紹介医初診時）
B : 1995年 7 月 ( 2 吕月後 $)$
C：1996年 2 月（ 9 か月後
D：1996年11月（18か月後）
E：1997年 1月（20か月後当科初診時）

ており、臨床的にはすでに腫瘍が発生していたものと思わ れるが，X線写真上では腫瘍の存在を示す所見は認められ ない.

1995年 7 月（2 か月後）: 根管処置後であるが, $\lfloor 1$ 部の 違和感は継続していた．まだ腫瘍を疑わせる所見は認めら れない

1996年 2 月（ 9 か月後）: 1 の挺出および根尖部に境 界不明瞭な透過像が認められるものの, 依然として腫痬を 思わせる所見は認められず, 歯根の吸収も明らかではない なお根管充填㓮は, 再根管処置のため除去されている。

1996年11月（18か月後）:はじめて，し1２＼cjkstart間に明らか な骨破壊像が認められた。

1997年 1月（20か月後, 当科初診時）：骨破壊像の中に不 透過像が現われ，歯根の吸収が認められた。

\section{考察}

顎骨骨肉腫の発生頻度は, 顎顔面部悪性腫瘍中 $1.4 \%{ }^{11}$, 全骨肉腫中では約 $\left.1 \sim 8 \%{ }^{1 \sim 3}\right)$ といわれている. 発生部 位は，前歯部よりも臼歯部に多い1，4）とされているが，上 下顎の差は明らかではない ${ }^{3)}$. 好発年齡は 10 台で，平均年 齢は30台 $1 ， 3)$ であり，性差は報告により異なる．また予後 は施設によりさまざまであるが，一般に長幹骨骨肉腫に比 べて良好とされている2，3，5)，骨肉腫は放射線や化学療法 に感受性が低く5), さらに顎骨骨肉腫は長幹骨骨肉腫に比
較して遠隔転移率が低い2こことから，主たる治療法は外科 的切除とされている．近年では遠隔転移を防ぐために，術 後にメソトレキセート大量療法を施行する場合 6 ) も多い が, 本症例では組織学的に低悪性と考えられたこと，また 腫場が歯槽骨に限局し鼻腔にまでおよんでいなかったこと から，外科的切除のみにとどめ，術後化学療法は行わな かったが, 現在まで再発を認めていない

骨肉腫のX線写真上の特徴は, 浸潤的な辺縁像, 点状の 骨様硬化像，spiculation，皮質骨の破壊像など?)であるが， 本症例では，点状の骨㥞硬化像が当科初診時に認められた ものの，その他の特徴にそしかったために診断が困難で あった

また，本症例のように腫瘍の発生初期と思われる段階か ら, 経時的にX 線写真上の変化を追えた症例は，きわめて 珍しいものと思われた。

\section{結}

\section{語}

上顎正中部に生じた低悪性度骨肉腫の 1 例を経験した。 臨床的に腫瘍が発生していたと思われる時期にX 線写真 上では異常所見が認められなかった。その後, 腫瘍による 骨破壊の状況をX 線写真上で経時的にとらえることがで きた. 外科的切除を施行したのみであるが, 術後 3 年経過し， 現在までに再発および転移を示唆する所見は認められない。

稿を終えるにあたり，貴重なデンタル X 線写真を御提供い ただいた松島海岸診療所歯科井上博之先生に深謝致します

本論文の要旨は第52回日本口腔科学会総会 (平成 10 年 4 月 16 日，松山）にて発表した。

\section{引用 文 献}

1）佐藤研一，露崎孝二，他：本邦に扔ける顎顔面部。 骨肉腫の統計的観察. 日口外誌 24: 1116-1126 1978.

2) Maldonado, A.B. and Spratt, J.S.: Osteogenic sarcoma of the mandible and maxilla. South Med J 79: 1453-1455 1986.

3）鈴木晶博, 亀谷明秀, 他 : 上顎骨に発生した骨肉腫 の 1 例および過去10年間における文献的考察．日口 外誌 33: 1789-1794 1987.

4) Tanzawa, H., Uchiyama, S., et al.: Statistical observation of osteosarcoma of the maxillofacial region in Japan. Oral Surg Oral Med Oral Pathol 72: 444-448 1991.

5）今西順久，志津木 健，他：上顎骨骨肉腫の治療経 験. 耳喉頭額 68: 318-323 1996.

6）三浦尚徳，野谷健一，他：下顎骨に生じた骨肉腫の 2 例. 日口外誌 35: 893-904 1989

7) Petrikowski, C.G., Pharoah, M.J., et al.: Radiographic differentiation of osteogenic sarcoma, osteomyelitis, and fibrous dysplasia of the jaws. Oral Surg Oral Med Oral Pathol 80: 744-750 1995. 